\title{
Correlation of Ultrasound Parameters with Serum Creatinine in Renal Parenchymal Disease
}

\author{
Khadka $\mathbf{H}^{1^{*}}$, Shrestha $\mathbf{B}^{2}$, Sharma $\mathbf{S}^{1}$, Shrestha $A^{3}$, Regmi $\mathbf{S}^{1}$, Ismail $A^{1}$, Thapa $\mathbf{G}^{1}$, Pathak $\mathbf{S}^{1}$ \\ 'Department of Radiology \& Imaging, National Academy of Medical Sciences, Bir hospital, \\ Kathmandu, Nepal, ${ }^{2}$ National Kidney Centre, Kathmandu, Nepal \\ ${ }^{3}$ Department of Radiology, National Academy of Medical Sciences, Trauma Centre, Kathmandu, Nepal
}

\section{Keywords}

Hypertension, Chronic kidney disease,

Renal cortical cysts,

Renal echogenicity,

Serum creatinine.

\section{Corresponding author}

*Dr. Hensan Khadka

Professor, Department of Radiology \& Imaging

National Academy of Medical Sciences

Bir hospital, Kathmandu, Nepal

Email: hensankhadka@yahoo.com

\section{ABSTRACT}

Introduction: Chronic kidney disease (CKD) is common cause of renal failure. It involves a progressive loss in the structure and function of the kidneys over the course of months, with or without decreased glomerular filtration rate (GFR). CKD can be diagnosed by its pathological abnormalities, changes in the levels of renal function markers in the blood or urine, or by imaging investigations (E.g. USG etc).

Objectives: The purpose of our study is 1) To correlate renal echogenicity with serum creatinine in order to determine the significance of renal echogenicity for identifying the progression of chronic kidney disease (CKD) and for the sonographic grading of CKD, 2) To study association of blood pressure, renal cortical cysts and renal size with grade of chronic renal disease.

Methods: This hospital based cross sectional study was carried out at National Kidney Centre, Banasthali Kathmandu. Two hundred patients above 20 years, diagnosed with CKD according to the guidelines of the National Kidney Foundation and referred for USG, were included in the study. Patients with kidney transplant, on dialysis, with liver disease and renal tumors were excluded. Ultrasound of kidneys was performed by senior consultant radiologist who was blind to the patients' serum creatinine levels. The relationship between grade of CKD with serum creatinine, kidney size, blood pressure and cortical cysts were assessed. Statistical analysis was performed by Kruskal wallis test using SPSS version 17. P values less than 0.05 were considered statistically significant.

Results: Mean serum creatinine was $1.7 \mathrm{mg} / \mathrm{dl}$ for Grade 1 (range: 1.1$4.7 \mathrm{mg} / \mathrm{dl}$, STD 0.44), $2.38 \mathrm{mg} / \mathrm{dl}$ for Grade 2 (range: $1.8-3.9 \mathrm{mg} / \mathrm{dl}$ STD 0.40 ), $4.18 \mathrm{mg} / \mathrm{dl}$ for Grade 3 (range: $2.6-6.0 \mathrm{mg} / \mathrm{dl}$, STD 0.88), and 5.65 $\mathrm{mg} / \mathrm{dl}$ for Grade 4 (range: $3.1-12 \mathrm{mg} / \mathrm{dl}$, STD 2.0.

Conclusion: Renal echogenicity and its grading correlates better with serum creatinine in CKD than other sonographic parameters. Hence, renal echogenicity is a better parameter than serum creatinine for estimating renal function in CKD, and has the added advantage of irreversibility. 


\section{INTRODUCTION}

The grade of kidney disease is determined by cortical echogenicity with Grade 1 mild form, Grade 2 moderate form, Grade 3 severe form and Grade 4 as end-stage renal disease ${ }^{1}$.

Chronic renal disease (CKD) is defined as:

1. Kidney damage $\geq 3$ months, as defined by structural or functional abnormalities of the kidney with or without decreasing GFR, manifest by either pathological abnormalities or markers of kidney damage including abnormalities in the composition of blood or urine or abnormalities in the imaging tests.

2. GFR $<60 \mathrm{ml} / \mathrm{min} / 1.73 \mathrm{~m}^{2}$ for $\geq 3$ months with or without kidney damage ${ }^{2}$.

Chronic Kidney disease is a worldwide public health problem, both for the number of patients and cost of treatment involved. Globally, CKD is the $12^{\text {th }}$ commonest cause of death and the $17^{\text {th }}$ commonest cause of disability, respectively ${ }^{1}$. The commonest cause of CKD is diabetic nephropathy ${ }^{3}$.

Renal ultrasound is simple, inexpensive and can be done at the bedside to provide the clinician with important anatomical details of the kidneys with a low inter-observer variability ${ }^{4}$. The safety of the diagnostic procedure using ultrasound is well established ${ }^{5}$. In the clinical practice, Ultrasonography is used in the initial evaluation of CKD patients for three major reasons as follows:

1. To rule out potentially reversible causes (E.g. collecting system dilatation).

2. To make a decision about a possible renal biopsy in cases where US fails to define the CKD etiology.

3. To obtain renal measurements as a prognostic factor. Such measurements are important since in most cases CKD leads to a common final-stage condition characterized by small kidneys, cortical and parenchymal thinning (indicating atrophy) and hyperechogenicity indicating sclerosis and fibrosis (small, dense, echogenic kidneys); such findings indicate disease irreversibility and poor prognosis ${ }^{6}$.

The measurement of serum creatinine has been the traditional approach to assessing CKD. The estimated GFR (Egfr) derived from formulas such as the Modification of Diet in Renal Disease (MDRD) equation is superior to serum creatinine alone in the diagnosis of CKD. ${ }^{7}$
Chronic kidney disease is one of the common causes of renal failure. It involves a progressive loss over the course of months in the structure and function of the kidneys, with or without a decreased glomerular filtration rate (GFR) ${ }^{8}$. CKD can be diagnosed by its pathological abnormalities, changes in the levels of kidney function markers in the blood or urine, or by imaging investigations 9 . Ultrasound is the ideal imaging modality in CKD because of its noninvasiveness, and because it provides easy accessibility and visualization of the kidneys. Ultrasonography is the first, and, in most cases, the only imaging investigation required in the work-up of chronic renal failure. Observation of a small kidney with a thin, echogenic cortex or parenchyma indicates irreversible damage ${ }^{10,11}$. The best screening modality to evaluate renal insufficiency in patients is sonography ${ }^{12}$. As ultrasonographic findings like echogenicity, longitudinal length, parenchymal, and cortical thickness represent irreversible changes, ultrasonography is a better imaging modality when it comes to ascertaining the progression of the disease ${ }^{10,11}$. The serum creatinine level is an endogenous serum marker that is commonly used to estimate GFR, and accordingly, the stage of $\mathrm{CKD}^{13}$.

Renal parenchymal disease is a group of disease of renal parenchyma which is broadly divided into glomerular, vascular and tubulointerstitial disease. There is substantial overlap amongst these disease entities with the end result being functional impairment.

After six months of age, the cortex should not be more echogenic than the liver, and there is progressive decrease in echogenicity so that the cortex is less echogenic than the liver in $90 \%$ of cases by the age of seven years ${ }^{14}$. It was known long before that renal length decreases with progression of renal parenchymal disease $\mathrm{e}^{15}$. The mean right renal length is $10.74 \pm 1.35 \mathrm{~cm}$ and the mean left renal length is $11.1 \pm 1.15 \mathrm{~cm}$, measured as the longest diameter obtained on a posterior oblique image, with a lower limit of normality generally indicated as $9 \mathrm{~cm}^{16}$. According to Fiorini et al, renal length under $8 \mathrm{~cm}$ is definitely reduced and should be attributed to chronic renal failure, whereas a length between 8 and $9 \mathrm{~cm}$ should always be correlated to the patient's phenotype, particularly the height ${ }^{17}$.

Study by Miletić et al ${ }^{18}$ revealed that relative renal length (calculated using the kidney length to body height ratio) better represents kidney size than absolute renal length (Measurements of longitudinal renal diameter) because it eliminates sex and height differences. In an attempt 
to improve differentiation of normal kidneys from those affected by chronic kidney disease, some authors have furthermore proposed the evaluation of renal volume using the ellipsoid formula $(\mathrm{V}=$ craniocaudal diameter anteroposterior diameter $\mathrm{x}$ transeverse diameter $\mathrm{x}$ $0.5233)^{19}$ subsequently adjusted to patient's body mass index.

\section{MATERIALS AND METHODS}

This hospital based cross sectional study was conducted at National Kidney Centre, Banasthali, Kathmandu, after approval by the ethical committee. The duration of study was three years, from May 2015 to April 2018. Two hundred patients above 20 years of age who had been diagnosed with CKD according to the guidelines of the National Kidney Foundation were selected ${ }^{9}$. Patients on hemodialysis, peritoneal dialysis, renal transplantation, those with fatty liver and other liver diseases diagnosed on ultrasonography, patients with renal tumors and those unwilling to give consent were excluded. Detailed information from patients regarding age sex, duration of diabetes mellitus if diabetic, duration of hypertension if hypertensive, other causes of chronic renal failure, and treatment history were collected. Using a standard B mode grayscale ultrasound (Medison, sonoace R7), ultrasonography of the kidneys was performed using curved array transducers of 2.5-4 MHz. Low tissue harmonic imaging was applied to visualize the kidney echogenicity. The radiologist was blind to patients' serum creatinine values. Renal longitudinal size (both Right and Left), cortical echogenicity, corticomedullary differentiation and associated renal cortical cysts were evaluated. Renal cortical echogenicity was compared and graded with the echogenicity of the liver, where:

Grade 0: Normal echogenicity less than that of the liver, with maintained corticomedullary definition.

Grade 1: Echogenicity the same as that of the liver, with maintained corticomedullary definition.

Grade 2: Echogenicity greater than that of the liver, with maintained corticomedullary definition.

Grade 3: Echogenicity greater than that of the liver, with poorly maintained corticomedullary definition

Grade 4: Echogenicity greater than that of the liver with a loss of corticomedullary definition.
Latest serum creatinine levels were obtained from patient's record. Statistical analysis was calculated by Kruskal wallis test using SPSS 17 version. The relationship between grade of CKD with serum creatinine, kidney size, blood pressure and cortical cysts were assessed. $P$ values less than 0.05 were considered statistically significant.

\section{RESULTS}

Out of 200 selected patients, 128 (64\%) were males and $72(36 \%)$ were females (Table1). Patient age was from 20 years to 86 years with mean age of 46.39 years. 31-40 year age group had the highest frequency of CKD (25\%) followed by 41 - 50 year age group (20.5\%). Least frequency was found in age group of $>80$ years $(3 \%)$ (Table 2). Sixty five patients (32.2\%) had sonological Grade 1 CKD, 63 (31.5\%) had Grade 2 CKD, 40 (20\%) had Grade 3 CKD, and 32 (16\%) had Grade 4 CKD (Table 3). Mean serum creatinine was $1.7 \mathrm{mg} / \mathrm{dl}$ for Grade 1 (Range: 1.1 - $4.7 \mathrm{mg} / \mathrm{dl}$, STD 0.44), 2.38mg/dl for Grade 2 (range: 1.8 - $3.9 \mathrm{mg} / \mathrm{dl}$ STD 0.40), $4.18 \mathrm{mg} / \mathrm{dl}$ for Grade 3 (range: 2.6 - $6.0 \mathrm{mg} / \mathrm{dl}$, STD 0.88), and $5.65 \mathrm{mg} / \mathrm{dl}$ for Grade 4 (range: 3.1 - $12 \mathrm{mg} / \mathrm{dl}$, STD 2.0 (Table 4). The mean longitudinal size of right kidney was $9.8 \mathrm{~cm}$ for Grade 1 (range: 8.9 $12.6 \mathrm{~cm}$, STD 0.8), $9.1 \mathrm{~cm}$ for Grade 2 (range: 9.1 - 10.9 $\mathrm{cm}$, STD 0.6), $8.2 \mathrm{~cm}$ for Grade 3 (Range: $6.1-9.3 \mathrm{~cm}$, std 0.9 ), and $7.1 \mathrm{~cm}$ for Grade 4 (range: $5.1-9.0 \mathrm{~cm}, \mathrm{STD}=1.0$ ) (Table 5). Mean longitudinal size for left kidney was $9.8 \mathrm{~cm}$ for grade 1 (Range $8.8-12.1 \mathrm{~cm}$, STD 0.7 ), $9.1 \mathrm{~cm}$ for grade 2 (Range 6.9 - $11 \mathrm{~cm}$, STD 0.67), $8.4 \mathrm{~cm}$ for grade 3 (Range 6.2-9.5 cm, STD 0.87) and $7.2 \mathrm{~cm}$ for grade 4 (Range 5.6 $9.2 \mathrm{~cm}$, STD 1.0) (Table 6).

Renal cortical cyst was present in $22(33.8 \%)$ in grade 1, $20(31.7 \%)$ in grade $2,18(45 \%)$ in grade 3 and $12(37.5 \%)$ in grade 4 patients (Table 7 ).

Table 1: Male to female ratio of study population

\begin{tabular}{llccccc} 
& & \multicolumn{4}{c}{ Grade (MRD) } & \multirow{2}{*}{ Total } \\
\cline { 3 - 6 } Sex & & 2 & 3 & 4 & & \\
& Male & 46 & 42 & 22 & 18 & 128 \\
\multirow{2}{*}{ Total } & Female & 19 & 21 & 18 & 14 & 72 \\
\hline
\end{tabular}

Table 2: Age group of the study population

\begin{tabular}{ccc}
\hline Age group (Years) & Number & Percentage (\%) \\
$20-30$ & 35 & 17.5 \\
$31-40$ & 50 & 25 \\
$41-50$ & 41 & 20.5
\end{tabular}




\begin{tabular}{ccc}
\hline Age group (Years) & Number & Percentage (\%) \\
$20-30$ & 35 & 17.5 \\
$31-40$ & 50 & 25 \\
$41-50$ & 41 & 20.5 \\
$51-60$ & 36 & 18 \\
$61-70$ & 20 & 10 \\
$71-80$ & 12 & 6 \\
$>80$ & 6 & 3 \\
Total & 200 & 100 \\
\hline
\end{tabular}

Table 3: Different grades of renal echogenicity in study population

\begin{tabular}{ccccccccc}
\hline $\begin{array}{c}\text { Grade } \\
\text { (MRD) }\end{array}$ & Mean & N & $\begin{array}{c}\text { Std. } \\
\text { Deviation }\end{array}$ & $\begin{array}{c}\text { Mini- } \\
\text { mum }\end{array}$ & $\begin{array}{c}\text { Maxi- } \\
\text { mum }\end{array}$ & $\begin{array}{c}\text { Std. } \\
\text { error } \\
\text { of } \\
\text { Mean }\end{array}$ & Sum & Range \\
\hline 1 & 44.14 & 65 & 16.587 & 20 & 81 & 2.057 & 2869 & 61 \\
2 & 47.43 & 63 & 16.343 & 20 & 86 & 2.059 & 2988 & 66 \\
3 & 49.83 & 40 & 14.629 & 28 & 84 & 2.313 & 1993 & 56 \\
4 & 44.59 & 32 & 16.000 & 22 & 84 & 2.828 & 1427 & 62 \\
Total & 46.39 & 200 & 16.075 & 20 & 86 & 1.137 & 9277 & 66 \\
\hline
\end{tabular}

Fig 1: Grade 4 renal cortical echogenicity with small kidney size

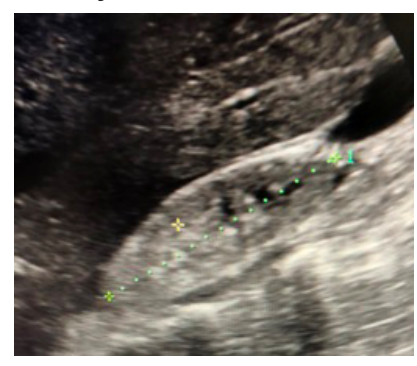

Fig 2: Grade 2 echogenic kidney with maintained CMD

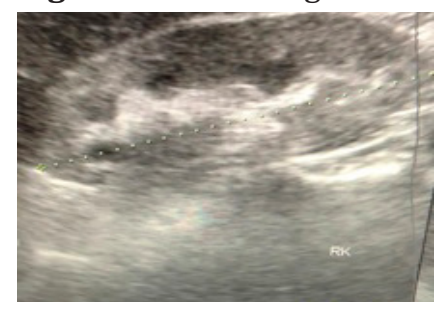

Table 4: Mean serum creatinine in each grade

\begin{tabular}{ccccccccc}
\hline $\begin{array}{c}\text { Grade } \\
\text { (MRD) }\end{array}$ & Mean & $\mathbf{N}$ & $\begin{array}{c}\text { Std. } \\
\text { Devia- } \\
\text { tion }\end{array}$ & $\begin{array}{c}\text { Mini- } \\
\text { mum }\end{array}$ & $\begin{array}{c}\text { Maxi- } \\
\text { mum }\end{array}$ & $\begin{array}{c}\text { Std. } \\
\text { error of } \\
\text { Mean }\end{array}$ & Sum & Range \\
\hline 1 & 1.732 & 65 & 0.4416 & 1.1 & 4.7 & 0.0548 & 112.6 & 3.6 \\
2 & 2.389 & 63 & 0.4017 & 1.8 & 3.9 & 0.0506 & 150.5 & 2.1 \\
3 & 4.183 & 40 & 0.8892 & 2.6 & 6.0 & 0.1406 & 167.3 & 3.4 \\
4 & 5.659 & 32 & 2.0111 & 3.1 & 12.0 & 0.3555 & 181.1 & 8.9 \\
Total & 3.058 & 200 & 1.7193 & 1.1 & 12.0 & 0.1216 & 611.5 & 10.9 \\
\hline
\end{tabular}

Table 5: Mean right renal size

\begin{tabular}{ccccccc}
\hline $\begin{array}{c}\text { Grade } \\
\text { (MRD) }\end{array}$ & Mean & N & $\begin{array}{c}\text { Std } \\
\text { Devia- } \\
\text { tion }\end{array}$ & $\begin{array}{c}\text { Mini- } \\
\text { mum }\end{array}$ & $\begin{array}{c}\text { Maxi- } \\
\text { mum }\end{array}$ & $\begin{array}{c}\text { Std } \\
\text { error of } \\
\text { mean }\end{array}$ \\
1 & 9.802 & 65 & 0.8100 & 8.9 & 12.6 & 0.1005 \\
2 & 9.113 & 63 & 0.6150 & 7.0 & 10.9 & 0.0775 \\
3 & 8.248 & 40 & 0.9747 & 6.1 & 9.3 & 0.1541 \\
4 & 7.131 & 32 & 1.0636 & 5.1 & 9.0 & 0.1880 \\
Total & 8.847 & 200 & 1.2477 & 5.1 & 12.6 & 0.0882 \\
\hline
\end{tabular}

Table 6: Mean left renal size

\begin{tabular}{ccccccccc}
\hline $\begin{array}{c}\text { Grade } \\
\text { (MRD) }\end{array}$ & Mean & N & $\begin{array}{c}\text { Std. } \\
\text { Devia- } \\
\text { tion }\end{array}$ & $\begin{array}{c}\text { Mini- } \\
\text { mum }\end{array}$ & $\begin{array}{c}\text { Maxi- } \\
\text { mum }\end{array}$ & $\begin{array}{c}\text { Std. } \\
\text { error of } \\
\text { Mean }\end{array}$ & Sum & Range \\
1 & 9.857 & 65 & 0.7697 & 8.8 & 12.1 & 0.0955 & 640.7 & 3.3 \\
2 & 9.171 & 63 & 0.6709 & 6.9 & 11.0 & 0.0845 & 577.8 & 4.1 \\
3 & 8.478 & 40 & 0.8743 & 6.2 & 9.5 & 0.1382 & 339.1 & 3.3 \\
4 & 7.238 & 32 & 1.0441 & 5.6 & 9.2 & 0.1846 & 231.6 & 3.6 \\
Total & 8.946 & 200 & 1.2046 & 5.6 & 12.1 & 0.0852 & 1789.2 & 6.5 \\
\hline
\end{tabular}

Table 7: Association of cortical cysts in echogenic grade

\begin{tabular}{|c|c|c|c|c|c|c|}
\hline & & \multicolumn{4}{|c|}{ Grade (MRD) } & \multirow[t]{2}{*}{ Total } \\
\hline & & 2 & 3 & 4 & & \\
\hline \multirow[t]{3}{*}{ Cysts } & Yes & 22 & 20 & 18 & 12 & 72 \\
\hline & No & 43 & 43 & 22 & 20 & 128 \\
\hline & Total & 65 & 63 & 40 & 32 & 200 \\
\hline
\end{tabular}

\section{DISCUSSION}

In our study, mean age was 46.39 year (Range 20 - 86 years) suggesting all age group are prone to the chronic renal disease. The highest frequency was seen in age group 31 - 40 years (25\%) followed by 41 - 50 years $(20.5 \%)$. The least frequent cases were in age group $>80$ years $(3 \%)$. Study by Singh A et $a l^{1}$ showed the mean age of 54.32 year (range 19 - 85 years). In their study, the most frequent age group was 51 - 60 years (33\%) followed by $41-50$ years $(31 \%)$ and least frequent was $>80$ years $(1 \%)$. In our study, male to female ratio was $1.77: 1$ with male : female ratio of $2.4: 1$ for Grade 1, $2: 1$ for Grade 2, 1.2:1 for Grade 3 and 1.28: 1 for Grade 4. Male to female ratio was $2.3: 1$ in study by Siddapa JK et $a l^{8}$ and it was $1.38: 1$ in study by Singh A et $a l^{1}$.

In our study, 65 patients (32.2\%) had sonological Grade 1 CKD, 63 (31.5\%) had Grade 2 CKD, 40 (20\%) had Grade 3 CKD, and 32 (16\%) had Grade 4 CKD (Table 2) which correlates well with study by Singh A et $a l^{1}$, which showed that 35 cases had Grade 1 echogenicity (35\%), 42 cases had Grade 2 echogenicity (42\%), 16 cases had Grade 3 echogenicity (16\%) and 7 cases had Grade 4 echogenicity 
(7\%). Study by Siddapa et $\mathrm{al}^{8}$ showed 29 patients (48.3\%) had sonological Grade 1 CKD, 21 (35\%) had Grade 2 CKD, 7 (11.7\%) had Grade 3 CKD, and 3 (5\%) had Grade 4 CKD.

The lower number of people in Grade 3 and Grade 4 may be an underestimate, as patients with CKD are more likely to die of cardiovascular disease than to reach EndStage Renal Disease (ESRD). Another reason may be due to the fact that, the institution is a tertiary referral center, most cases were treated with renal replacement therapies like hemodialysis, peritoneal dialysis, and renal transplantation due to complications associated with CKD, therefore excluded from the study.

Raised renal cortical echogenicity was reported in all the patients with CKD in our study which correlated with study by Singh A et $\mathrm{al}^{1}$ and siddapa JK et al ${ }^{8}$. In our study, there was no difference in echogenicity between two kidneys suggesting that changes occur in CKD patients bilaterally and symmetrically, whereas study by Singh A et $a l^{1}$, showed four cases (4\%) had difference in the echogenicity of the two kidneys, Paivansalo $\mathrm{M}$ et $a^{2^{1}}$ also reported that an echogenic cortex was the most common abnormality detected.

In our study CMD (corticomedullary differentiation) was maintained in 128 patients ((64\%), poorly maintained in 40 patients $(20 \%)$ and lost in 32 patients (16\%). It correlates well with study by Singh A et al ${ }^{1}$, where cortico-medullary differentiation was maintained in $77 \%$ of the cases, poorly maintained in $16 \%$ of the cases and it was lost in $7 \%$ of the cases and study by Siddappa JK et $a l^{8}$, who had $83.3 \%$ of cases with maintained corticomedullary differentiation, $11.7 \%$ with poorly maintained cortico-medullary differentiation and in $5 \%$ of the cases the cortico-medullary differentiation was lost.

In our study, Mean serum creatinine was $1.7 \mathrm{mg} / \mathrm{dl}$ for Grade 1 (Range: 1.1 - $4.7 \mathrm{mg} / \mathrm{dl}$, STD 0.44), $2.38 \mathrm{mg} / \mathrm{dl}$ for Grade 2 (Range: 1.8 - $3.9 \mathrm{mg} / \mathrm{dl}$ STD 0.40), $4.18 \mathrm{mg} / \mathrm{dl}$ for Grade 3 (Range: 2.6 - $6.0 \mathrm{mg} / \mathrm{dl}$, STD 0.88), and $5.65 \mathrm{mg} /$ $\mathrm{dl}$ for Grade 4 (range: 3.1 - $12 \mathrm{mg} / \mathrm{dl}$, STD 2.0 (Table 4). This showed statistically significant correlation between grading of chronic kidney disease and serum creatinine ( $p$ value $<0.001$ ). In study by Singh A et $a l^{1}$, The mean serum creatinine values were $2.87 \mathrm{mg} / \mathrm{dL}$ for Grade 1 echogenicity (Range 1.8 - $5.6 \mathrm{mg} / \mathrm{dL} ; \mathrm{SD}=0.81$ ), $3.26 \mathrm{mg} / \mathrm{dL}$ for Grade 2 echogenicity (Range $1.6-6.1 \mathrm{mg} / \mathrm{dL} ; \mathrm{SD}=1.09$ ), $4.3 \mathrm{mg} / \mathrm{dL}$ for Grade 3 echogenicity (Range 2.7 - $7.5 \mathrm{mg} / \mathrm{dL}$; $\mathrm{SD}=1.58$ ) and $5.81 \mathrm{mg} / \mathrm{dL}$ for Grade 4 echogenicity (Range 3.6 $9.5 \mathrm{mg} / \mathrm{dL} ; \mathrm{SD}=5.81$ ). In study by Siddapa JK et $a l^{8}$, Mean serum creatinine was $2.80 \mathrm{mg} / \mathrm{dl}$ for Grade 1 (Range: 0.9 - $9.2 \mathrm{mg} / \mathrm{dl}$ ), $3.69 \mathrm{mg} / \mathrm{dl}$ for Grade 2 (Range: 1.2 - $10.3 \mathrm{mg} /$ dl), $3.86 \mathrm{mg} / \mathrm{dl}$ for Grade 3 (range: $1.1-6.5 \mathrm{mg} / \mathrm{dl}$ ), and $7.90 \mathrm{mg} / \mathrm{dl}$ for Grade 4 (range: 3.1 - $11.4 \mathrm{mg} / \mathrm{dl}$ ). Our study showed significant positive correlation between grade of cortical echogenicity and serum creatinine. Same results were shown in study by Singh A et $a l^{1}$ and Siddapa JK et $a l^{8}$. Moghazi $\mathrm{S}$ et $a l^{20}$ also supported this finding by stating that renal echogenicity had the strongest correlation with histological parameters (Glomerular sclerosis, tubular atrophy, interstitial fibrosis and interstitial inflammation). Paivansalo et $a l^{21}$ also reported that an echogenic cortex was the most common abnormality detected Hricak et $a l^{22}$ showed a statistically significant positive correlation between cortical echogenicity and the severity of global sclerosis, focal tubular atrophy, the number of hyaline casts per glomerulus and focal leucocytic infiltration.

Our results contradict those of Platt JF et al ${ }^{23}$, who found that renal echogenicity equal to the echogenicity of the liver is not a good indicator of disease.

In our study, right kidney was small $(<8 \mathrm{~cm})$ in $42(21 \%)$, normal in $157(78.5 \%)$ and enlarged $(>12 \mathrm{~cm})$ in $1(0.5 \%)$ whereas left kidney was small in $35(17.5 \%)$ normal in $164(82 \%)$ and enlarged in one case $(0.5 \%)$. In none of the cases, size discrepancy between two kidneys was found more than $2 \mathrm{~cm}$ (maximum size discrepancy of $1.9 \mathrm{~cm}$ was found in only one case) suggesting that both kidneys were symmetrically involved in chronic kidney disease. In a study by Arvinder et $\mathrm{al}^{1}, 35 \%$ had small size, 3\% had enlarged size and $62 \%$ had normal sized kidneys. Size discrepancy of $>2 \mathrm{~cm}$ was found between two kidneys in $4 \%$ cases. This study had close result to our study.

In our study, The mean longitudinal size of right kidney was $9.8 \mathrm{~cm}$ for Grade 1 (Range: $8.9-12.6 \mathrm{~cm}$, STD 0.8), 9.1 for Grade 2 (Range: 9.1 - 10.9, STD 0.6), 8.2 for Grade 3 (Range: 6.1 - 9.3, STD 0.9), and $7.1 \mathrm{~mm}$ for Grade 4 (Range: $5.1-9.0 \mathrm{~cm}, \mathrm{STD}=1.0$ ) and Mean longitudinal size for left kidney was $9.8 \mathrm{~cm}$ for Grade 1 (Range 8.8 - 12.1, STD 0.7 ), $9.1 \mathrm{~cm}$ for Grade 2 (Range 6.9 - 11, STD 0.67), $8.4 \mathrm{~cm}$ for Grade 3 (Range $6.2-9.5 \mathrm{~cm}$, STD 0.87) and $7.2 \mathrm{~cm}$ for Grade 4 (Range 5.6 - $9.2 \mathrm{~cm}$, STD 1.0). This showed that with increasing grade of CKD, the mean kidney length of both kidneys decreased, showing significant correlation between these two parameters (P value $<0.001$ ). In study by Siddapa $e t \mathrm{al}^{8}$, The mean longitudinal size was 101.38 mm for Grade 1 (Range: 76 - $124 \mathrm{~mm}$ ), $91.43 \mathrm{~mm}$ for Grade 2 (Range: 63 - $115 \mathrm{~mm}$ ), $89.43 \mathrm{~mm}$ for Grade 3 (range: 60 - $111 \mathrm{~mm}$ ), and $78 \mathrm{~mm}$ for Grade 4 (Range: 67 - $91 \mathrm{~mm}$ ). In 
a study by Singh A et $\mathrm{al}^{1}$, the average kidney length measured was $8.69 \mathrm{~cm}$ (Range, $6.6-15.45 \mathrm{~cm}$; SD = $1.35 \mathrm{~cm}$ ). Both these study results correlate with our study.

In our study, renal cortical cysts were present in 72 patients (36\%). Renal cortical cyst was present in 22 (33.8\%) in Grade 1, $20(31.7 \%)$ in Grade 2, 18 (45\%) in Grade 3 and $12(37.5 \%)$ in Grade 4 patients. But this relation was not statistically insignificant ( $\mathrm{P}$ value 0.54). In a study by Arvinder et $a l^{1}, 9 \%$ of patients had associated renal cortical cysts.

In our study, 165 (82.5\%) had increased BP whereas 35 (17.5\%) had normal BP with 49.2\% having increased BP for Grade 1, 96.8\% having increased BP for Grade 2, 100\% having increased BP for Grade 3 and 100\% having increased BP for Grade 4 indicating that with increase in Grade of CKD, blood pressure was found to increase (Increase in BP may be both cause and effect of CKD).

\section{CONCLUSION}

Renal echogenicity and its grading correlates better with serum creatinine in CKD than other sonographic parameters. Hence, renal echogenicity is a better parameter than serum creatinine for estimating renal function in CKD, and has the added advantage of irreversibility. Chronic renal disease was also associated with increased blood pressure and decreased kidney size.

\section{Conflict of Interest}

None

\section{Funding}

None

\section{REFERENCES}

1. Singh A, Gupta K, Chander R, Vira M. Sonographic grading of renal cortical echogenicity and raised serum creatinine in patients with chronic kidney disease. J Evolution Med Dent Sci. 2016; 5(38): 2279-2286, DOI: $10.14260 /$ jemds/2016/530

2. Levey AS, Coresh J, Balk E, et al. National kidney foundation practice guidelines for chronic kidney disease: evaluation, classification, and stratification. Ann Intern Med. 2003; 139(2): 137-47.
3. Agarwal SK, Srivastava RK. Chronic kidney disease in India: challenges and solutions. Nephron Clin Pract. 2009; 111(3): 197-203.

4. Emamian SA, Nielsen MB, Pedersen JF. Intraobserver and interobserver variations in sonographic measurements of kidney size in adult volunteers a comparison of linear measurements and volumetric estimates. Acta Radiol. 1995; 36(4): 399-401.

5. Hergesell O, Felten H, Andrassy K, et al. Safety of ultrasound-guided percutaneous renal biopsyretrospective analysis of 1,090 consecutive cases. Nephrol Dial Transplant. 1998; 13(4): 975-77.

6. Yamashita SR, Von Atzingen $\mathrm{AC}$, Iared $\mathrm{W}$, et al. Value of renal cortical thickness as a predictor of renal function impairment in chronic renal disease patients. Radiologia Brasileira. 2015; 48(1): 12-6

7. Duru OK, Vargas RB, Kermah D, et al. High prevalence of stage 3 chronic kidney disease in older adults despite normal serum creatinine. J Gen Intern Med. 2008; 24(1): 86-92.

8. Siddappa JK, Singla S, Al Ameen M, et al. Correlation of ultrasonographic parameters with serum creatinine in chronic kidney disease. J Clin Imaging Sci. 2013; 3: 28.

9. National Kidney Foundation. Bailie GR, Uhlig K, Levey AS. Clinical practice guidelines in nephrology. Evaluation, classification, and stratification of chronic kidney disease. Am J Kidney Dis. 2002; 39(suppl 2): S1-266.

10. O'Neill WC. Chronic renal failure. In: O'Neill WC, editor. Atlas of renal ultrasonography. Philadelphia: W.B. Saunders Company; 2001. pp. 41-3.

11. O'Neill WC. Sonographic evaluation of renal failure. Am J Kidney Dis. 2000; 35: 1021-38.

12. Khati NJ, Hill MC, Kimmel PL. The role of ultra-sound in renal insufficiency: The essentials. Ultrasound $Q$. 2005; 21: 227-44.

13. Tietz NW. Philadelphia: W.B. Saunders Co; 1994. Textbook of Clinical Chemistry. p. 1531.

14. Vade A, Lau P, Smick J, Harris V, Ryva J. Sonographic renal parameters as related to age. Pediatric Radiology. 1987; 17: 212-5. 
15. Sargent M, Long G, Karmali M, Cheng SM. Interobserver variation in the sonographic estimation of renal volume in children. Pediatric Radiology.1997; 27: 663-6.

16. Webb JA, Reznek R, White F, Catell W, Fry IK, Baker L. Can ultrasound and computed tomography replace high- dose urography in patients with impaired renal function? QJM. 1984; 53: 411-25.

17. Fiorini F, Barozzi L. The role of ultrasonography in the study of medical nephropathy. J Ultrasound. 2007; 10(4): 161-7. doi:10.1016/j.jus.2007.09.001

18. Miletić D, Fuckar Z, Sustić A, Mozetic V, Stimac D, Zauhar G. Sonographic measurement of absolute and relative renal length in adults. J Clin Ultrasound. 1998; 26: 185-9.

19. Han BK, Babcock DS. Sonographic measurements and appearance of normal kidneys in children. American Journal of Roentenology. 1985; 145: 6116.

20. Moghazi S, Jones E, Schroepple J, et al. Correlation of renal histopathology with sonographic findings. Kidney Int. 2005; 67(4): 1515-20.

21. Päivänsalo $M$, Huttunen $K$, Suramo I. Ultrasonographic findings in renal parenchymal diseases. Scand J Urol Nephrol. 1985; 19(2): 119-23.

22. Hricak H, Cruz C, Romanski R, et al. Renal parenchymal disease: Sonographic histologic correlation. Radiology. 1982; 144(1): 1417.

23. Platt JF, Rubin JM, Bowerman RA, Marn CS. The inability to detect kidney disease on the basis of echogenicity. Am J Roentgenol. 1988; 151: 317-9. 